\title{
Estudo químico de óleos essenciais, oleaginosas e látices da Amazônia. I. Composição e oxidação do óleo de uma espécie de Copaifera (Nota prévia).
}

\author{
J. G. Soares Maia( $\left(^{*}\right)$, M. J. C. Varejão( $\left.{ }^{*}\right)$, W. Wolter Filho( $\left.{ }^{*}\right)$, A. P. Mourão( $\left.{ }^{* *}\right)$, A. A. Craveiro( $\left(^{* *}\right)$ \\ e J. W. Alencar $(* *)$
}

Um estudo do óleo-resina e do óleo obtido das sementes de uma espécie de Copaifera, usando como método analítico, GC/MS, HPLC e volumetria, está sendo desenvolvido na Divisão de Química do INPA em colaboração com o Departamento de Química da Universidade Federal do Ceará, para determinação de seus constituintes químicos e controle cinético de autoxidação com e sem adição de agentes antioxidantes e sinergísticos.

O óleo-resina é constituído pelos sesquiterpenos $\beta$-elemeno, $\propto$-copaeno, $\beta$-cariofileno, $\propto$-humuleno, $\beta$-bisaboleno, 4-cadineno, cubebeno, $\propto$-ylangeno, $\propto$-multijugenol e óxido de cariofileno. Desses, apenas o cubebeno e o $\propto$-cadineno não haviam sido registrados na literatura como constituintes de um óleo de copaíba.

O estudo da autoxidação do óleo-resina a $45^{\circ} \mathrm{C}$ revelou uma variação de 0,45 no número de peróxido durante 24 horas, expressos em meq de $\mathrm{O}_{2} / \mathrm{g}$ de óleo. Observações no compor- tamento do uso dos antioxidantes Gemini, NESVO, Galato de propila e $\propto$-tocoferol nas concentrações de 1,0 e $0,1 \%$ mostraram que $\propto$-tocoferol apresenta maior efeito inibidor da oxidação.

O óleo obtido das sementes é constituído por cumarina $(0,15 \%)$ e dos seguintes ácidos graxos: palmítico $(24,9 \%)$, oleico $(35,3 \%)$, linoleico $(35,7 \%)$, araquídico $(1,1 \%)$ e beenico $(3,0 \%)$.

\section{SUMMARY}

Preliminar note on a study of the resin oil (from the trunk) and the seed oil from a species of Copaifera was done, using the analytical methods known as GC/MS and HPLC and the volumetric method. This work was developed at the Divisão de Quimica of the INPA in collaboration with the Departamento de Química of the UFCe with the purpose to identify the chemical components and to establish the kinetic control of auto oxidaticn with and without the addition of antioxidants and synergistic agents.

( - ] - Instituto Nacional de Pesquisas da Amazônia, Manaus.

("*) - Fundação Universidade do Amazonas.

(***) - Universidade Federal do Ceará. 